\title{
Penambahan Asam Amino Triptofan Dalam Pakan Terhadap Tingkat Kanibalisme Dan Pertumbuhan Litopenaeus vannamei
}

\author{
Diana Rachmawati 1*, Johannes Hutabarat', Ayu Istiana Fiat', Tita Elfitasari', \\ Seto Windarto', Eko Nur Cahyo Dewi ${ }^{2}$ \\ 'Departemen Akuakultur, Fakultas Perikanan dan Ilmu Kelautan, Universitas Diponegoro \\ 2Departemen Teknologi Hasil Perikanan, Fakultas Perikanan dan Ilmu Kelautan, \\ Universitas Diponegoro \\ JI. Prof. Soedarto SH, Tembalang, Semarang 50275 \\ E-mail: dianarachmawati1964@gmail.com
}

\begin{abstract}
The Addition of Tryptophan Amino Acid in Feed on the Rate of Cannibalism and Growth of Litopenaeus vannamei
\end{abstract}

\begin{abstract}
Vannamei shrimp (Litopenaeus vannamei) is one of the leading fishery products of the fisheries sector. The problem that is often found in the failure of vannamei shrimp productions is the high level of mortality due to the nature of cannibalism during molting. One solution to minimize the cannibalism of vannamei shrimp is to provide tryptophan supplements in a feed. Tryptophan is a type of essential amino acid that serves as a precursor for serotonin biosynthesis. This study aims to determine the effect and optimal dose of tryptophan added to feed to reduce cannibalism and growth of vannamei shrimp. The test fish used in this study were vannamei shrimp with an average weight of $0,81 \pm 0,26 \mathrm{~g} /$ individual. This study used an experimental method, a completely randomized design (CRD) consisting of 4 treatments and three replications. The test feed used in this study was artificial feed with a protein content of $38 \%$ plus tryptophan according to treatments A $(0 \% / \mathrm{kg}$ feed), B $(0.75 \% / \mathrm{kg}$ feed), $C(1.5 \% / \mathrm{kg}$ feed), and $D(2.25 \% / \mathrm{kg}$ feed). The results showed that the addition of Tryptophan in the feed had a noticeable effect $(P<0,05)$ on cannibalism levels, survival, and molting rates but had no significant effect $(P>0,05)$ on absolute weight growth, specific growth rates, efficiency ratios protein and efficiency feed utilization of vannamei shrimp. The best dose of tryptophan addition in feed to lower the rate of vannamei shrimp cannibalism in this study was $2,25 \%$, capable of producing a cannibalism rate of $13,33 \%$.
\end{abstract}

Keywords: cannibalism; growth; tryptophan; vannamei shrimp

\begin{abstract}
Abstrak
Udang vaname (Litopenaeus vannamei) merupakan salah satu produk perikanan unggulan sektor perikanan. Permasalahan yang sering ditemukan dalam kegagalan produksi udang vaname adalah tingginya tingkat mortalitas karena adanya sifat kanibalisme pada saat terjadi molting. Solusi untuk meminimalisir kanibalisme udang vaname adalah dengan memberi suplemasi asam amino pada pakan, salah satunya adalah triptofan. Triptofan merupakan salah satu jenis asam amino esensial yang berfungsi sebagai prekursor untuk biosintesis serotonin. Penelitian ini bertujuan untuk mengkaji pengaruh dan dosis optimal triptofan yang ditambahkan ke dalam pakan untuk menurunkan tingkat kanibalisme dan pertumbuhan udang vaname. Ikan uji yang digunakan pada penelitian ini adalah udang vaname dengan bobot rata-rata $0,81 \pm 0,26 \mathrm{~g} / \mathrm{ekor}$. Penelitian ini menggunakan metode eksperimen, rancangan acak lengkap (RAL) yang terdiri atas 4 perlakuan dan 3 kali ulangan. Pakan uji yang digunakan dalam penelitian ini adalah pakan buatan dengan kandungan protein $38 \%$ ditambah triptofan sesuai perlakuan yaitu : A $(0 \% / \mathrm{kg}$ pakan), B $(0,75 \% / \mathrm{kg}$ pakan, $C(1,5 \% / \mathrm{kg}$ pakan), dan D $(2,25 \% / \mathrm{kg}$ pakan). Hasil penelitian menunjukkan bahwa
\end{abstract}


penambahan triptofan dalam pakan berpengaruh nyata $(P<0,05)$ terhadap tingkat kanibalisme, kelulushidupan dan tingkat molting, namun tidak berpengaruh nyata $(P>0,05)$ terhadap pertumbuhan bobot mutlak, laju pertumbuhan spesifik, protein efisiensi rasio dan efisiensi pemanfaatan pakan. Dosis terbaik dari pemberian triptofan dalam pakan untuk menurunkan tingkat kanibalisme udang vaname dalam penelitian ini adalah 2,25\%, mampu menghasilkan tingkat kanibalisme sebesar $13,33 \%$.

Kata Kunci : kanibalisme, pertumbuhan, triptofan, udang vaname

\section{PENDAHULUAN}

Udang vaname (Litopenaeus vannamei) merupakan salah satu produk perikanan unggulan sektor perikanan. Vaname merupakan salah satu jenis udang yang sering dibudidayakan. Hal ini disebabkan udang tersebut memiliki prospek dan profit yang menjanjikan (Ravuru \& Mude, 2014). Udang vaname memiliki keunggulan antara lain lebih tahan penyakit, pertumbuhan lebih cepat, tahan terhadap gangguan lingkungan, waktu pemeliharaan lebih pendek (90-100 hari), survival ratenya (SR) tergolong tinggi (>80\%) dan menempati semua kolom air (Schock et al., 2013). Salah satu permasalahan yang sering ditemukan dalam kegagalan produksi udang vaname adalah tingginya tingkat mortalitas karena adanya sifat kanibalisme pada saat terjadi molting. Kanibalisme pada umumnya berhubungan dengan genetik dan kebiasaan hidup. Perbedaan ukuran yang ada dalam kelompok karena variasi genetik menjadi penyebab utama (Purnamasari et al., 2017). Sifat kanibalisme disebabkan oleh adanya perbedaan ukuran di antara larva dan faktor ketersediaan pakan (kualitas dan kuantitas) dalam suatu permukaan air (Hseu et al., 2003; Höglund et al., 2005; Król dan Zakęs, 2016; Kumar et al., 2017). Solusi untuk meminimalisasi kanibalisme udang vaname (L. vannamei) adalah dengan memberi suplemen asam amino pada pakan, salah satunya adalah triptofan. Penambahan tryptophan dalam pakan akan mengoptimalkan aktivitas neuron serotonik, sehingga dapat mengontrol sifat kanibalisme pada ikan (Hseu et al., 2003; Höglund et al., 2005; Król dan Zakęś, 2016; Kumar et al., 2017; Muslimin et al., 2011).

Triptofan merupakan salah satu jenis asam amino essensial yang penting bagi pertumbuhan ikan, selain itu triptofan juga merupakan prekursor untuk sintesis serotonin dalam otak. Semakin tinggi konsumsi triptofan oleh ikan, maka cenderung produksi serotonin dalam otaknya juga meningkat. Semakin tinggi kadar serotonin dalam otak, maka tingkat agresif ikan cenderung menurun (Suharyanto, 2012). Asam amino triptofan merupakan salah satu asam amino esensial yang kandungannya terbatas dalam beberapa bahan pakan, dan sering menjadi faktor pembatas bagi pertumbuhan ikan (Usman et al., 2016). Penambahan triptofan ke dalam pakan untuk mengatasi depresi dan sifat agresif biasanya digunakan dosis triptofan 1-3 g/hari. Proses perubahan triptofan menjadi serotonin diperlukan triptofan hidroksilase dengan menggunakan vitamin B6 dan enzim karboksilase. Peningkatan triptofan dalam pakan, akan menghasilkan peningkatan aktivitas serotonin dan penurunan sifat agresif/stres (Muslimin et al., 2011).

Penelitian penambahan triptofan dalam pakan pada beberapa spesies ikan dilaporkan oleh Suharyanto (2008), mengemukakan bahwa penambahan 1,5\% triptofan dalam pakan ini dapat menekan tingkat kanibalisme rajungan dan berbeda nyata $(P<0,05)$ dengan kontrol. Menurut Suharyanto et al. (2014), penambahan asam amino triptofan dalam pakan pelet sebanyak $1,5 \%$ dari total biomassa, dapat menekan tingkat kanibalisme udang galah. Trisnasari et al. (2020), mengemukakan tingkat kanibalisme terendah lobster air tawar (Cherax quadricarinatus) terdapat pada penambahan dosis triptofan $1-2 \%$ yaitu sebesar $10 \pm 7,07 \%$. Hseu et al. (2003), mengemukakan bahwa tingkat kanibalisme dapat ditekan dengan penambahan $0,5 \%$ triptofan dalam pakan juvenil ikan kerapu lumpur (Epinephelus coioides) dan Kamaruddin et al. (2006), mengemukakan tingkat kanibalisme dapat ditekan dengan penambahan 1,0\% triptofan 
dalam pakan kerapu macan (E. Fuscoguttatus). Hoglund et al. (2005) melaporkan bahwa suplementasi triptofan dalam pakan mengurangi kanibalisme pada rainbow trout (Onchorhyncus mykiss). Kumar et al. (2017) merekomendasikan 0,5\% Ttiptofan dalam pakan dapat mengurangi kanibalisme dan meningkatkan kelangsungan hidup benih ikan Asian seabass (Lates calcarifer).

Dari uraian tersebut diatas dapat disimpulkan bahwa kebutuhan triptofan pada setiap spesies ikan berbeda. Informasi penelitian penambahan triptofan dalam pakan untuk udang vaname belum banyak ditemukan, maka pentingnya penelitian ini dilakukan untuk menekan tingkat kanibalisme. Tujuan dari penelitian ini adalah untuk mengkaji pengaruh penambahan asam amino triptofan pada pakan terhadap tingkat kanibalisme dan pertumbuhan udang vaname serta mengkaji dosis asam amino triptofan yang tepat yang dicampur dalam pakan untuk mengurangi tingkat kanibalisme udang vaname.

\section{MATERI DAN METODE}

Penelitian ini dilaksanakan di Balai Besar Perikanan Budidaya Air Payau (BBPBAP), Jepara, Jawa Tengah pada bulan Februari s/d April 2021. Hewan uji berupa udang vaname yang diperoleh dari pokdakan di Jepara

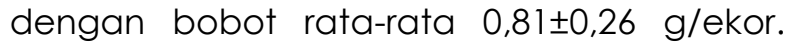
Sebelum pelaksanaan penelitian dilakukan adaptasi udang terhadap pakan dan lingkungan selama satu minggu. Pakan buatan komersial tanpa penambahan asam amino triptofan diberikan selama proses adaptasi. Udang dipuasakan selama satu hari sebelum dilakukan penelitian untuk menghilangkan sisa metabolisme dalam tubuh udang. Udang vaname yang digunakan sebagai hewan uji dipilih yang berukuran seragam, aktif berenang, sehat dan tidak cacat (Rachmawati et al., 2017). Pemberian pakan selama penelitian dilakukan dengan menggunakan metode fix feeding rate sebanyak 10\%/ bobot biomassa/hari dan frekuensi pemberian pakan diberikan sebanyak 3 kali sehari pada pukul 08.00, 14.00 dan 20.00 WIB.

Metode penelitian yang digunakan adalah rancangan acak lengkap (RAL), 4 perlakuan dan 3 ulangan. Pakan uji yang digunakan dalam penelitian ini adalah pakan buatan dengan kandungan protein $38 \%$ ditambah triptofan sesuai perlakuan A $10 \% / \mathrm{kg}$ pakan), B $(0,75 \% / \mathrm{kg}$ pakan, C $(1,5 \% / \mathrm{kg}$ pakan), dan D (2,25\%/kg pakan). Penentuan dosis triptofan memodifikasi dari penelitian Suharyanto (2012) yang melaporkan bahwa triptofan dosis $1,5 \%$ memberikan tingkat kanibalisme terendah untuk udang windu (Penaeus monodon). Triptofan murni yang digunakan adalah L-Tryptophan yang berbentuk bubuk berwarna putih. Metode pencampuran triptofan dalam pakan dilakukan dengan cara repeleting yaitu menghaluskan pakan buatan terlebih dahulu menggunakan blender. Kemudian melarutkan triptofan sesuai perlakuan dengan air, setelah homogen maka triptofan dicampurkan pada pakan yang sudah dihaluskan dan ditambahkan CMC $1 \%$. Kemudian adonan pakan yang sudah dicampur homogen dicetak Kembali, dikeringkan dengan menggunakan oven suhu $40^{\circ} \mathrm{C}$ hingga kering (Trisnasari et al., 2020). Selanjutnya dilakukan uji analisa proksimat untuk mengetahui kandungan nutrisi dalam pakan uji yang dan hasil analisa proksimat pakan uji disajikan pada Tabel 1.

Wadah penelitian yang digunakan dalam penelitian ini adalah ember plastik dengan kapasitas 25-liter berjumlah 12 ember yang masing-masing dilengkapi dengan sistem resirkulasi. Penempatan wadah penelitian dilakukan secara acak dengan air media budidaya salinitas 31 ppt. Masingmasing ember diisi udang vaname dengan padat penebaran 1 ekor/liter. Pengamatan parameter kualitas air selama penelitian meliputi salinitas, DO, pH, suhu, dan amonia. Pemeliharaan kualitas air dilakukan dengan cara penyiponan sebanyak 2 hari sekali yaitu pada pagi hari. Penyiponan dilakukan untuk membersihkan media budidaya agar tetap bersih dan layak untuk kehidupan udang vaname. Parameter yang diamati meliputi adalah efisiensi pemanfaatan pakan (EPP), rasio efisiensi protein (PER), pertumbuhan bobot mutlak (WG), laju pertumbuhan spesifik (SGR), frekuensi molting (MFq), tingkat kanibalisme (TK), kelulushidupan (SR) dan parameter kualitas air.

Efisiensi pemanfaatan pakan dihitung menggunakan rumus Tacon (1987) berikut : 


$$
E P P=\frac{W t-W o}{F} \times 100 \%
$$

Keterangan: EPP $=$ Efisiensi pemanfaatan pakan (\%); Wt= Biomassa ikan uji pada akhir penelitian (g); $W 0=$ Biomassa ikan uji pada awal penelitian (g); $F=$ Jumlah pakan ikan yang diberikan selama penelitian (g)

Perhitungan rasio efisiensi protein menggunakan rumus Tacon (1987) sebagai berikut:

$$
P E R=\frac{W t-W o}{P i} \times 100 \%
$$

Keterangan: PER = Protein Efisiensi Rasio (\%); $\mathrm{Wt}=$ Biomassa ikan uji pada akhir penelitian (g); $W 0=$ Biomassa ikan uji pada awal penelitian (g); $\mathrm{Pi}=$ Bobot protein pakan yang dikonsumsi (g)

Menurut Effendi (1997), perhitungan pertumbuhan bobot mutlak dihitung dengan menggunakan rumus sebagai berikut:

$$
W G=W_{t}-W_{0}
$$

Keterangan: $W G=$ Pertumbuhan mutlak (g); $\mathrm{W}_{\mathrm{t}}=$ Bobot rata-rata akhir pemeliharaan (g); $W_{0}=$ Bobot rata-rata awal pemeliharaan (g)

Perhitungan laju pertumbuhan spesifik menurut Zonneveld et al. (1991) sebagai berikut:

$$
S G R=\frac{\ln W t-\ln W o}{t}
$$

Keterangan: $S G R=$ Laju pertumbuhan relatif (\%/hari); Wt= Biomassa ikan uji pada akhir penelitian (g); Wo= Biomassa ikan uji pada awal penelitian (g); $\dagger=$ Lama percobaan (hari)

Menurut Handayani dan Syahputra (2018), frekuensi molting dapat dihitung dengan rumus sebagai berikut:

$$
M F q=\frac{X m o l t}{N t o t} \times 100 \%
$$

Keterangan: $M F q=$ Frekuensi molting; $X_{\text {molt }}=$ Jumlah udang yang molting; $\mathrm{N}_{\text {tot }}=$ Jumlah udang pada masa penelitian

Menurut Hseu et al. (2003), perhitungan tingkat kanibalisme dihitung dengan menggunakan rumus sebagai berikut:

$$
T K \frac{K a-K h-K m b a k}{K a} \times 100 \%
$$

Keterangan: $\mathrm{TK}=$ Tingkat kanibalisme (\%); $\mathrm{K}_{\mathrm{a}}=$ Jumlah ikan awal (ekor); $K_{h}=$ Jumlah ikan tersisa/hidup (ekor); Kmbak= Jumlah ikan mati bukan akibat kanibalisme (ekor)

Perhitungan kelulushidupan menggunakan rumus Effendi (1997) sebagai berikut :

$$
\mathrm{SR}=\frac{\mathrm{Nt}}{\mathrm{No}} \times 100 \%
$$

Keterangan: $\mathrm{SR}=$ Kelulushidupan; $\mathrm{N}_{\mathrm{o}}=$ Jumlah ikan pada awal penelitian; $\mathrm{N}=$ Jumlah ikan pada akhir penelitian

Data pengamatan parameter yang yang telah diperoleh dianalisis mengguakan analisis ragam (ANOVA) pada taraf kepercayaan $95 \%$ dan $99 \%$ untuk melihat pengaruh perlakuan. Apabila dalam analisis ragam diperoleh berpengaruh nyata $(P<0,05)$ atau berpengaruh sangat nyata $(P<0,01)$, maka dilakukan uji wilayah ganda duncan untuk mengetahui perbedaan antar perlakuan (Steel et al., 1996).

\section{HASIL DAN PEMBAHASAN}

Hasil analisis proksimat kandungan nutrisi pakan uji yang digunakan penelitian dapat dilihat pada Tabel 1 .

Hasil analisis proksimat pakan uji pada Tabel 1 menunjukkan bahwa semakin tinggi dosis asam amino triptofan dalam pakan akan semakin tinggi kandungan protein pakan uji. Data efisiensi pemanfaatan pakan (EPP), rasio efisiensi protein (PER), pertumbuhan bobot mutlak (WG), laju pertumbuhan spesifik (SGR), frekuensi molting (MFq), tingkat kanibalisme (TK), kelulushidupan (SR) udang vaname dan parameter kualitas air selama penelitian disajikan pada Tabel 2.

Pada Tabel 2. dapat dilihat asam amino triptofan dalam pakan tidak berpengaruh nyata terhadap EPP, PER, WG dan SGR, namun berpengaruh nyata terhadap $(P<0,05)$ MFq, TK dan SR udang vaname Hasil pengukuran kualitas air media budidaya udang vaname selama penelitian disajikan 
pada Tabel 3. menunjukkan bahwa kualitas air selama penelitian masih dalam kisaran nilai yang disarankan pustaka dan layak untuk udang vaname.

Pemberian asam amino triptofan pada pakan tidak memberikan pengaruh nyata $(P>0,05)$ terhadap pertumbuhan bobot mutlak dan laju pertumbuhan spesifik udang vaname. Hal ini mungkin karena pakan uji tidak memiliki profil EAA yang mirip dengan profil EAA udang vaname. Disamping itu kebutuhan asam amino esensial yang dibutuhkan untuk pertumbuhan udang vaname seperti arginine, histidine, isoleucine, leucine, lysine, methionine, phenylalanine, threonine dan valine belum terpenuhi, hanya asam amino triptofan saja yang sudah terpenuhi. Menurut Lovell (1998), kebutuhan asam amino udang vaname adalah sebagai berikut: Arginine $8,54 \%$, histidine $1,86 \%$, isoleucine $3,4 \%$, leucine $3,4 \%$, lysine $6,97 \%$, methionine $2,48 \%$, phenylalanine $3,39 \%$, threonine $2,69 \%$, tryptophan $1,27 \%$ dan valine $3,38 \%$. Pakan yang sesuai bagi ikan untuk pertumbuhan adalah pakan yang memiliki profil asam amino esensial yang mendekati sama dengan profil asam amino esensial ikan (Akiyama et al., 1992).

Penambahan asam amino triptofan pada pakan juga menurunkan kandungan lemak pakan uji hingga 4,5\% (Tabel 1). Menurut Sholikhuddin et al. (2019), untuk udang vaname kadar lemak yang dibutuhkan antara 5,5\%-15\%. Lemak merupakan sumber energi tinggi yang dibutuhkan untuk menunjang pertumbuhan udang. Saltin et al. (2016) menyatakan bahwa kandungan lemak yang optimal dalam pakan akan menghasilkan pertumbuhan yang optimal bagi hewan uji yang mengkonsumsinya. Menurut Rahman et al. (2018), bahwa keberadaan lemak mempunyai mempunyai peranan penting untuk pertumbuhan dan kelangsungan hidup, terutama beberapa tipe asam lemak sangat berpengaruh pada kehidupan udang.

Menurut Djunaedi, (2016) terdapat dua faktor yang mempengaruhi molting pada krustasea yaitu faktor eksternal dan faktor internal. Faktor eksternal meliputi adanya stressor, nutrisi, photoperiod dan temperatur, sedangkan faktor internal terkait dengan produksi hormon ekdisteroid dan Molt Inhibiting Hormone (MIH). Lebih lanjut Safitrah et al. (2020) mengemukakan molting dipengaruhi oleh umur udang, jika udang masih kecil maka akan sering mengalami molting, sebaliknya jika udang semakin besar maka frekuensi molting akan semakin kecil. Semakin sering udang molting maka semakin cepat pula pertumbuhan udang. Menurut Haliman dan Adijaya (2005), aktivitas molting udang vaname ditandai seringnya muncul ke permukaan air sambil meloncat-loncat, gerakan ini bertujuan membantu melonggarkan kulit luar udang dari tubuhnya.

Molting merupakan proses alami dalam kehidupan udang, karena kulit udang tidak elastis, tersusun oleh senyawa chitin yang keras. Molting terjadi akibat dampak dari proses hormonal dalam tubuh udang. Saat molting terjadi udang sangat rentan terhadap ancaman kanibalisme dari udang lainnya (Djunaedi, 2016). Udang sangat rentan terhadap serangan dari udang lainnya saat molting, karena kondisinya sangat lemah. Udang yang mengalami molting akan mengalami perubahan tekstur tubuhnya menjadi lunak. Udang vaname yang diberi pakan kandungan triptofan $2,25 \%$ (D) diperoleh frekuensi molting terendah yaitu sebesar $28,33 \%$. Hal ini diduga karena udang vaname yang diberi pakan dosis $2,25 \%$ menggunakan sebagian besar energi dan

Tabel 1. Hasil analisis proksimat kandungan nutrisi pakan uji

\begin{tabular}{ccccccc}
\hline \multirow{2}{*}{ Perlakuan } & \multicolumn{7}{c}{ Parameter } \\
\cline { 2 - 7 } & Protein & Karbohidrat & Lemak & Abu & Air & Serat Kasar \\
\hline A & 38,00 & 25,5 & 5,0 & 16,00 & 12,00 & 3,50 \\
B & 39,50 & 24,0 & 4,8 & 15,89 & 11,39 & 4,42 \\
C & 40,90 & 23,3 & 4,5 & 15,48 & 11,06 & 4,76 \\
D & 41,81 & 21,5 & 4,5 & 16,85 & 10,79 & 4,55 \\
\hline
\end{tabular}


Tabel 2. Data efisiensi pemanfaatan pakan (EPP), rasio efisiensi protein (PER), pertumbuhan bobot mutlak (WG), laju pertumbuhan spesifik (SGR), frekuensi molting (MFq), tingkat kanibalisme (TK), kelulushidupan (SR) udang vaname selama penelitian

\begin{tabular}{lrrrr}
\hline \multirow{2}{*}{ Parameter } & \multicolumn{4}{c}{ Perlakuan } \\
\cline { 2 - 5 } & $\mathrm{A}(0 \%)$ & $\mathrm{B}(0,75 \%)$ & $\mathrm{C}(1,5 \%)$ & $\mathrm{D}(2,25 \%)$ \\
\hline EPP (\%) & $29,74 \pm 2,15 \mathrm{a}$ & $27,21 \pm 2,08 \mathrm{a}$ & $26,38 \pm 1,95 \mathrm{a}$ & $25,25 \pm 1,67 \mathrm{a}$ \\
PER & $0,68 \pm 0,06^{a}$ & $0,64 \pm 0,06^{a}$ & $0,56 \pm 0,05 \mathrm{a}$ & $0,52 \pm 0,05 \mathrm{a}$ \\
WG (g) & $3,26 \pm 0,25 \mathrm{a}$ & $2,77 \pm 0,20 \mathrm{a}$ & $2,68 \pm 0,14 \mathrm{a}$ & $2,50 \pm 0,12^{\mathrm{a}}$ \\
SGR (g/hari) & $4,66 \pm 0,44 \mathrm{a}$ & $4,34 \pm 0,16 \mathrm{a}$ & $4,32 \pm 0,24 \mathrm{a}$ & $4,25 \pm 0,20 \mathrm{a}$ \\
MFq (\%) & $45,00 \pm 4,00 \mathrm{c}$ & $36,67 \pm 2,89 \mathrm{~b}$ & $33,33 \pm 2,89 \mathrm{ab}$ & $28,33 \pm 2,60 \mathrm{a}$ \\
TK (\%) & $31,67 \pm 2,89 \mathrm{c}$ & $28,33 \pm 2,55 \mathrm{bc}$ & $20,00 \pm 1,44 \mathrm{ab}$ & $13,33 \pm 1,05 \mathrm{a}$ \\
SR & $61,67 \pm 2,89 \mathrm{a}$ & $65,00 \pm 5,00 \mathrm{a}$ & $80,00 \pm 5,00^{\mathrm{b}}$ & $83,33 \pm 5,77 \mathrm{~b}$ \\
\hline
\end{tabular}

Keterangan: Nilai dengan superskrip yang sama pada kolom menunjukkan tidak adanya perbedaan yang nyata $(P>0,05)$

Tabel 3. Hasil pengukuran kualitas air selama penelitian

\begin{tabular}{cccccc}
\hline \multirow{2}{*}{ Perlakuan } & \multicolumn{5}{c}{ Kisaran Nilai Parameter Kualitas Air } \\
\cline { 2 - 6 } & Suhu $\left({ }^{\circ} \mathrm{C}\right)$ & $\mathrm{DO}(\mathrm{mg} / \mathrm{L})$ & $\mathrm{pH}$ & Salinitas $(\mathrm{pp})$ & $\mathrm{NH}_{3}(\mathrm{mg} / \mathrm{L})$ \\
\hline $\mathrm{A}$ & $27,0-31,2$ & $4,0-4,6$ & $7,1-7,8$ & $30-31$ & $0,01-0,05$ \\
$\mathrm{~B}$ & $27,0-31,4$ & $4,2-4,7$ & $7,0-7,7$ & $30-31$ & $0,02-0,04$ \\
$\mathrm{C}$ & $27,3-30,8$ & $4,2-4,6$ & $7,0-7,7$ & $30-31$ & $0,01-0,04$ \\
$\mathrm{D}$ & $28,0-31,0$ & $4,1-4,7$ & $7,2-7,8$ & $30-31$ & $0,01-0,06$ \\
Kelayakan & $26,0-32,0 \mathrm{a}$ & $4,0-6,0 \mathrm{a}$ & $7,0-8,5 \mathrm{~b}$ & $0,5-38,3 \mathrm{~b}$ & $<0,1^{\mathrm{b}}$ \\
\hline
\end{tabular}

Keterangan : aSNI (2014), bSaoud et al., (2013)

protein dari pakan untuk proses metabolisme tubuh dan sisanya untuk molting. Energi yang dibutuhkan untuk proses molting sangat besar, apabila kebutuhan energi tidak terpenuhi maka menyebabkan tingkat molting pada udang menjadi lambat. Hal ini diperkuat oleh Djunaedi (2016), yang menyatakan bahwa proses ganti kulit (molting) memerlukan energi dari pakan yang cukup besar. Energi yang diperlukan dalam proses molting cukup besar, jika protein dipakai sebagai sumber energi tidak mencukupi maka hal tersebut juga dapat menyebabkan kematian pada saat molting. Selain energi, proses molting juga dipengaruhi kandungan mineral kalsium dalam pakan. Menurut Fitriana et al. (2019), bahwa frekuensi molting sangat berpengaruh pada pakan, karena pakan yang dikonsumsi oleh udang harus memenuhi kalsium yang tinggi sehingga proses moltingnya dapat berjalan lancar, dan juga dengan adanya kalsium yang cukup proses pengerasan cangkang udang akan lebih cepat, sehingga dapat terkendalinya kanibalisme. Data frekuensi molting udang vaname selama penelitian dapat dilihat pada Tabel 4.
Mengukur tingkat kanibalisme udang vaname, maka dapat dilakukan dengan mengetahui tingkat pemangsaan. Kandungan triptofan dalam pakan memberikan pengaruh nyata $(P<0,05)$ terhadap tingkat kanibalisme udang vaname. Penambahan triptofan kedalam pakan dosis $2,25 \%$ (D) mampu menurunkan tingkat kanibalisme dan menghasilkan kanibalisme terendah yaitu sebesar 13,33\% (Gambar 1). Hal ini diduga karena penambahan triptofan dalam pakan yang mampu mengoptimalkan aktivitas neuron serotonik, sehingga dapat mengontrol sifat kanibalisme pada udang vaname. Serotonin ini berfungsi untuk menekan agresivitas, selain itu serotonin dapat mengalami metabolisme membentuk melatonin. Melatonin merupakan hormon yang bekerja secara langsung untuk mempengaruhi aktivitas organ. Adanya pembentukan serotonin dan melatonin ini maka akan terjadi akumulasi efek menenangkan sehingga udang vaname akan menjadi lebih tenang dan mengalami penurunan agresivitasnya (Kumar et al. (2017). Tingkat Kanibalisme udang vaname pada 
perlakuan A lebih tinggi dan berbeda nyata dibandingkan dengan perlakuan B, C, dan D. Hal ini disebabkan tidak ada penambahan triptofan dalam pakan, sehingga tidak ada yang mengendalikan organ otak, akhirnya berdampak pada peningkatan kematian udang vaname akibat sifat kanibalisme.

Bahan baku pakan secara umum mengandung triptofan, akan tetapi jumlah triptofan yang dibutuhkan untuk mengurangi sifat kanibalisme belum cukup, sehingga diperlukan penambahan triptofan. Hasil penelitian Gambar 1 menunjukkan penambahan triptofan ke dalam pakan terjadi penurunan sifat kanibal pada udang vaname. Hal ini berhubungan dengan dosis triptofan yang diberikan, di mana dosis triptofan yang tinggi akan meningkatkan kandungan triptofan dalam otak sehingga dapat mengurangi sifat agresif pada udang vaname. Peningkatan kandungan triptofan dalam pakan meningkatkan aktivitas serotonergik otak ikan dengan efek pelepas stres (Lepage et al., 2002) atau penurunan agresi (Hseu et al., 2003; Hoglund et al., 2005).

Proses perubahan triptofan menjadi serotonin diperlukan triptofan hidroksilase dengan menggunakan vitamin B6 dan enzim karboksilase. Hal ini didukung oleh pernyataan Muslimin et al. (2011), bahwa proses kerja triptofan dalam otak berhubungan dengan serotonin yaitu monoamine neurotransmitter yang disintesis di dalam serotonergic neurons dalam sistem syaraf pusat (central nervous system) dan sel enterochromaffin dalam sistem pencernaan (gastrointestinal tract) pada binatang termasuk manusia. Awalnya serotonin diidentifikasi sebagai sebuah vasoconstrictor substance dalam serum darah. Dalam sistem syarat pusat, serotonin berperan penting dalam mengatur sifat agresif. Di dalam tubuh, serotonin disintesis dari asam amino triptofan melalui metabolic pathway yang berisi 2 enzim yaitu triptofan hidroksilase (TPH) dan amino acid dekarboksilase.

Pemberian asam amino triptofan dalam pakan berpengaruh nyata $(P<0,05)$ terhadap kelulushidupan udang vaname. Udang vaname yang diberi pakan mengandung asam amino triptofan $2,25 \%$ memiliki nilai kelulushidupan tertinggi (83,33\%) dibandingkan dengan perlakuan lainnya. Hal ini diduga disebabkan karena produksi serotonin yang meningkat dalam otak sehingga mampu menurunkan sifat agresivitas pada udang vaname dan memberikan efek menenangkan sehingga tidak menimbulkan sifat kanibalisme pada saat terjadi molting. Apabila tingkat kanibalisme rendah maka nilai kelulushidupan akan tinggi. Begitu juga sebaliknya, apabila tingkat kanibalisme tinggi maka nilai kelulushidupan akan rendah karena banyak udang yang mati akibat kanibalisme (Appelbaum dan Arockiaraj, 2010). Hal ini bisa dilihat Tabel 2. ditunjukkan udang vaname diberi pakan mengandung asam amino triptofan $2,25 \%$ memiliki nilai tingkat molting terendah $(28,33 \%)$ dan nilai kelulushidupan tertinggi $(83,33 \%)$.

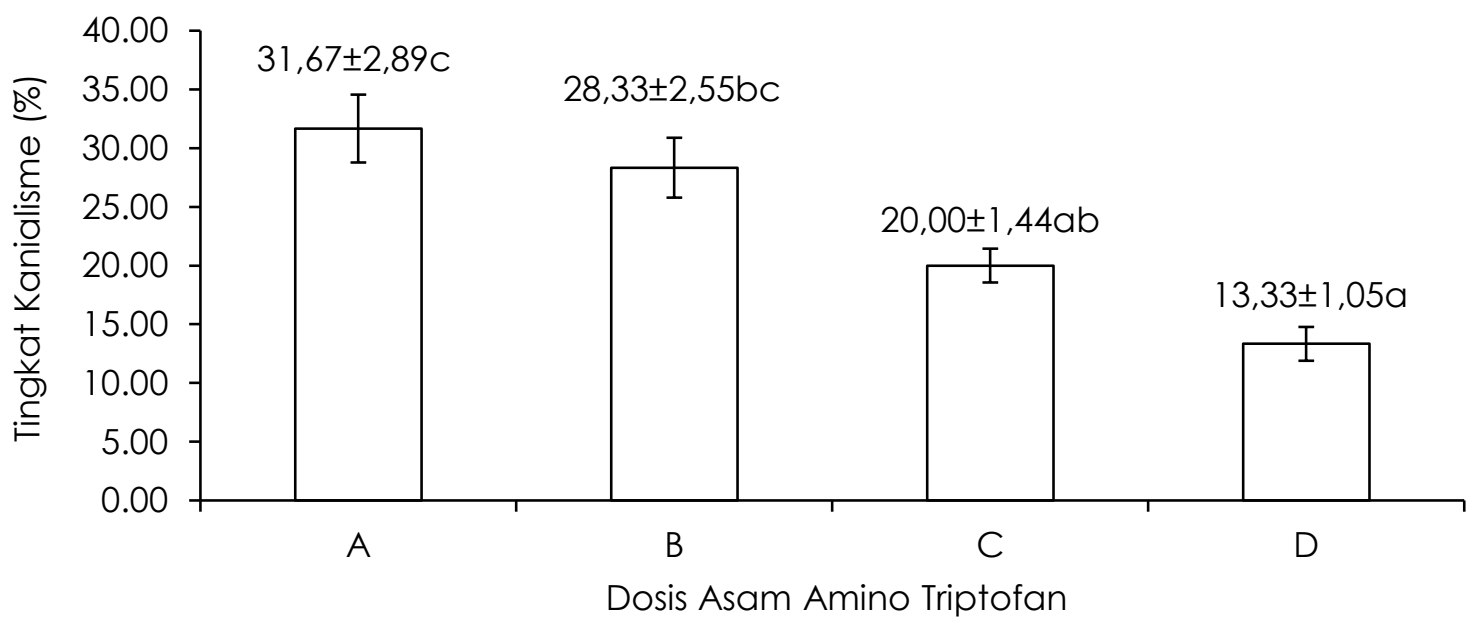

Gambar 1. Histogram tingkat kanibalisme udang vaname selama penelitian 
Tabel 4. Frekuensi molting udang vaname selama penelitian

\begin{tabular}{ccccc}
\hline \multirow{2}{*}{ Ulangan } & \multicolumn{5}{c}{ Perlakuan } \\
\cline { 2 - 5 } & $\mathrm{A}$ & $\mathrm{B}$ & $\mathrm{C}$ & $\mathrm{D}$ \\
\hline 1 & 50,00 & 35,00 & 35,00 & 30,00 \\
2 & 40,00 & 35,00 & 30,00 & 30,00 \\
3 & 45,00 & 40,00 & 35,00 & 25,00 \\
\hline Rata-rata & $45,00 \pm 4,00^{a}$ & $36,67 \pm 2,89 \mathrm{~b}$ & $33,33 \pm 2,89 \mathrm{c}$ & $28,33 \pm 2,60^{d}$ \\
\hline
\end{tabular}

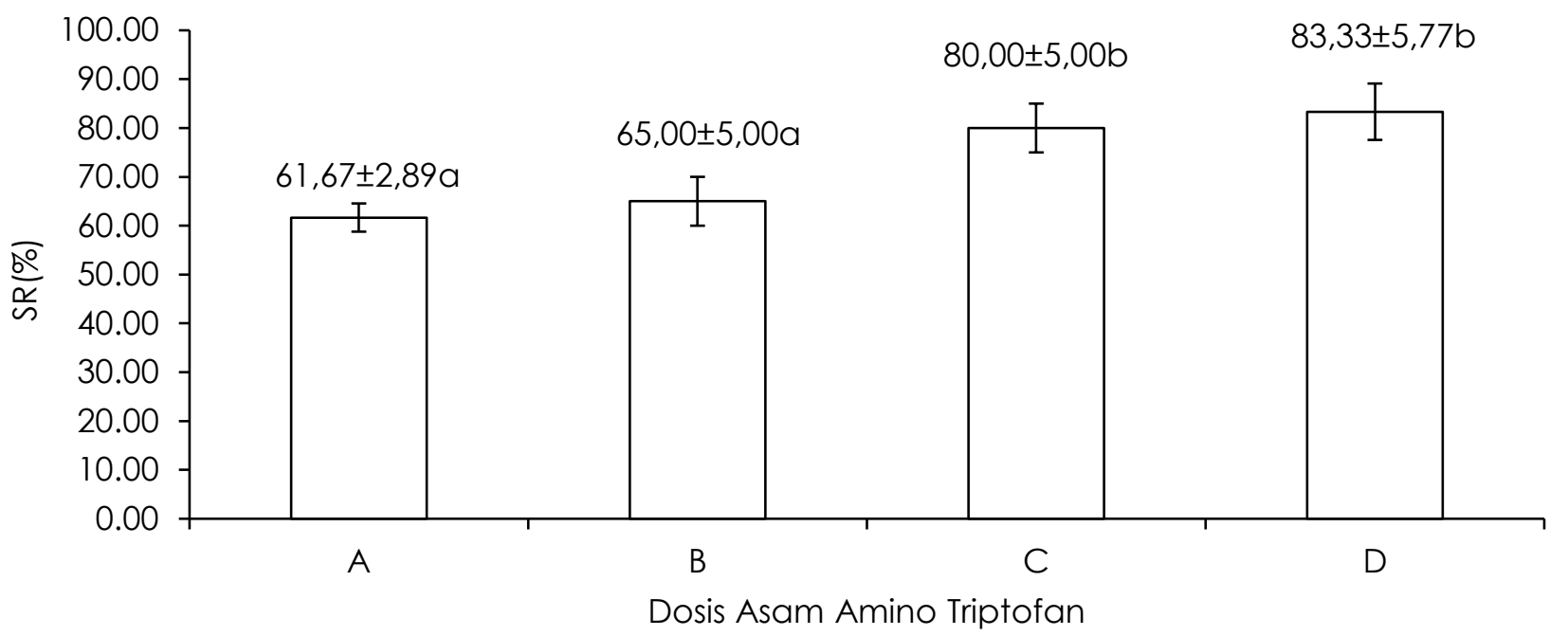

Gambar 2. Histogram kelulushidupan udang vaname selama penelitian

\section{KESIMPULAN}

Kandungan asam amino triptofan dalam pakan memberikan pengaruh nyata $(P<0,05)$ terhadap frekuensi molting, tingkat kanibalisme, kelulushidupan, namun tidak memberikan pengaruh nyata terhadap efisiensi pemanfaatan pakan (EPP) dan protein efisiensi rasio (PER), pertumbuhan bobot mutlak dan laju pertumbuhan spesifik (SGR) udang vaname. Dosis terbaik pemberian triptofan ke dalam pakan untuk mengurangi tingkat kanibalisme udang vaname pada penelitian ini adalah 2,25\%, yaitu menghasilkan tingkat kanibalisme terendah sebesar 13,33\%.

\section{UCAPAN TERIMA KASIH}

Terima kasih penulis ucapkan kepada kepala Balai Besar Perikanan Budidaya Air Payau (BBPBAP) Jepara yang telah menyediakan tempat dan fasilitas untuk pelaksanaan penelitian ini dan semua pihak yang telah membantu kelancaran penelitian ini.

\section{DAFTAR PUSTAKA}

Akiyama, D.M, Domny, W.G. \& Lawrence, A.L. 1992. Penaeid shrimp nutrition. Elsevier Publication, Amsterdam, $568 \mathrm{pp}$.

Appelbaum, S. \& Arockiaraj, A.J. 2010. Sibling Canibalism in Juvenile Asian Sea Bass ( $L$. calcarife) Reared Under Different Photoperiods. AACL Bioflux, 3(5):384-492.

Djunaedi, A. 2016. Pertumbuhan dan Prosentase Molting pada Kepiting Bakau (Scylla serrata Forsska I, 1775) dengan Pemberian Stimulasi Molting Berbeda. Jurnal Kelautan Tropis, 19(1): 29-36. doi: 10.14710/jkt.v19i1.597.

Effendi, I. 1997. Metode Biologi Perikanan. Yayasan Pustaka Nusantara. Yogyakarta.

Fitriana, Handayani, L. \& Nurhayati. 2019. Penambahan Nanokalsium Cangkang Tiram (Crassostrea gigas) pada Pakan dengan Dosis Berbeda terhadap Pertumbuhan Udang Galah (Macrobachium rosenbergii). Aquatic Sciences Journal, 6(2):80-85. doi: 10.291 03/aa.v6i2.1423. 
Handayani, L. \& F. Syahputra. 2018. Perbandingan Frekuensi Molting Lobster Air Tawar (Cherax quadricarinatus) yang Diberi Pakan Komersil dan Nanokalsium yang Berasal Dari Cangkang Tiram (Crassostrea gigas). Depik, 7(1):76-83.

Höglund, E., Bakke, M.J., Øverli, Ø., Winberg, S., \& Nilsson, G.E. 2005. Suppression of aggressive behaviour in juvenile Atlantic cod (Gadus morhua) by L-tryptophan supplementation. Aquaculture. 249(14):525-531.

Hseu, J.R., Lu, F.I., Su, H.M., Wang, L.S., Tsai, C.L. \& Hwang, P.P. 2003. Effect of Exogenus Triptophan on Canibalism, Survival and Growth in Juvenile Grouper. Taiwan Fisheries Indonesia. FRDP. Puslitbang Perikanan. Jakarta. Indonesia. 126 pp.

Kamaruddin, Usman \& Rachmansyah. 2006. Pengaruh Penambahan Triptofan terhadap Tingkat Kanibalisme, Sintasan dan Pertumbuhan Juwana Ikan Kerapu Macan, Epinephelus fuscoguttatus. Seminar Nasional dan Temu Bisnis Ikan Kerapu. 10hlm.

Król, J. \& Zakęś, Z. 2016. Effect of dietary Ltryptophan on cannibalism, survival and growth in pikeperch Sander lucioperca (L.) post-larvae. Aquaculture International. 24(2):441-451. doi: 10.1007/s10499-015-9936-1.

Kumar, P., Kailasam, M., Sethil, S.N., Sukumaran, K., Biswas, G., Subburaj, R., Thiagarajan, S., Ghoshal, T.K. \&Vijayan, K.K. 2017. Effect of dietary L-tryptophan on cannibalism, growth and survival of Asian seabass, Lates calcarifer (Bloch, 1790) fry. Indian Journal of Fisheries. 64:28-32. doi: 10.21077/ijf.2017.64.2.61333-05.

Lepage, O., Tottmar, O. \& Winberg, S. 2002. Elevated dietary intake of L-tryptophan counteracts the stress-induced elevation of plasma cortisol in rainbow trout (Oncorhynchus mykiss). The Journal of Experimental Biology, 205(23): 3679-3687.

Lovell, T. 1998. Nutrition and feeding of fish. Second Edition. Kluwer Academic Publishers. Norwell. Massachusetts. USA. Halaman 267.

Muslimin, Haryati, \& Trijuno, D.D. 2011. Penambahan Dosis Tryptophan dalam Pakan untuk Mengurangi Sifat Kanibalisme pada Larva Kerapu Macan
(Epinephelus fuscoguttatus). Jurnal Riset Akuakultur, 6(2):271-279. doi: 10.15578/jra. 6.2.2011.271-279.

Purnamasari, I., Purnama, D. \& Utami, M.A.F. 2017. Pertumbuhan Udang Vaname (Litopenaeus vannamei) di Tambak Intensif. Jurnal Enggano. 2(1):58-67.

Rachmawati, D., Istiyanto, S. \& Maizirwan, M. 2017. Effect of Phytase on Growth Performance, Feed Utilization Efficiency and Nutrient Digestibility in Fingerlings of Chanos chanos (Forsskal 1775). Philippine Journal of Science, 146(3):237-245.

Rahman, R., Lahming \& Fadillah, R. 2018. Evaluasi Komponen Gizi pada Pakan Udang Fermentasi. Jurnal Pendidikan Teknologi Pertanian, 4:101-111.

Ravuru, D.B. \& Mude, J.N. 2014. Effect of density on growth and production of Litopenaeus vannamei of brackish water culture system in summer season with artificial diet in Prakasam District, India. American International Journal of Research in Formal, Applied \& Natural Sciences, 14(108):10-13.

Safitrah, L., Setyowati, D.N. \& Astriana, B.H. 2020. Efektivitas Ekstrak Kulit Pisang Kepok (Musa balbisiana colla) dalam Pakan Komersial untuk Menurunkan Kanibalisme pada Udang Vaname (Litopenaeus vannamei). Jurnal Kelautan, 13(1):36-44. doi: 10.21 107/jk.v13i1.5941.

Saltin, A., M. Idris \& A. Kurnia. 2016. Pengaruh Penambahan Minyak Ikan Salmon dalam Pakan terhadap Pertumbuhan dan Sintasan Post Larva Udang Windu (Penaeus monodon). Jurnal Media Akuatika, 1 (4): 234-242.

Saoud, I.P., Davis, D.A. \& Rouse, D.B. 2003. Suitability Studies of Inland Well Waters for Litopenaeus vannamei Culture. Aquaculture, 217:373-383. doi: 10.1016/S0044-8486(02)0 0418-0

Schock, T.B., Duke, J., Goodson, A., Weldon, D., Brunson, J., Leffler, J.W. \& Bearden, D.W. 2013. Evaluation of Pacific White Shrimp (Litopenaeus vannamei) Health During a Super-intensive Aquaculture Growout Using NMR-Based Metabolism. PloS ONE. 8(3):e59251. doi: 10.1371/ journal.pone.0059521.

Sholikhuddin, G., Agus, M. \& Mardiana, T.Y. 2019. Pengaruh Perbedaan Persentase Pakan Buatan dan Fermentasi Bungkil 
Kedelai terhadap Pertumbuhan Udang Vaname (Litopenaeus vannamei). Jurnal Pena Akuatika. 18(2):34-46.

SNI. 2014. Produksi Induk Udang Vaname (Litopenaeus vannamei) Model Indoor. Badan Standardisasi Nasional. Jakarta. 7 hlm.

Steel, R.G.D., Torrie, J.H. \& Dickey, D.A. 1996. Principles and Procedures of Statistics: A Biometrical Approach. 3rd Edition, McGraw Hill, Inc. Book Co., New York, pp: 352-358.

Suharyanto, Aryati, Y. \& Tahe, S. 2008. Upaya Penurunan Tingkat Kanibalisme Rajungan (Portunus pelagicus) dengan Pemberian Suplemen Triptofan. Jurnal Perikanan, 10(1):126-133.

Suharyanto. 2012. Upaya Penurunan Tingkat Kanibalisme Udang Windu (Penaeus monodon) dengan Penambahan Dosis Suplemasi Triptofan yang Berbeda. Jurnal Biosfera, 29(1):16-22. doi: 10.20884/1.mib. 2012.29.1.230
Tacon, A.E.J. 1987. The Nutrition and Feeding Formed Fish and Shrimp a Training Manual Food and Agriculture of United Nation Brazilling, Brazil. $108 \mathrm{p}$.

Trisnasari, V., Subandiyono \& Hastuti, S. 2020. Pengaruh Triptofan dalam Pakan Buatan terhadap Tingkat Kanibalisme dan Pertumbuhan Lobster Air Tawar (Cherax quadricarinatus). Jurnal Sains Aquaculture Tropis, 4(1):19-30. doi : 10.14710/sat.v4i1.60 64

Usman, Kamaruddin \& Laining, A. 2016. Pengaruh Kadar Triptofan Pakan terhadap Pertumbuhan dan Sintasan Krablet Kepiting Bakau (Scylla serrata) Selama Masa Pendederan. Jurnal Riset Akuakultur, 11 (3):259-269. doi : 10.15578/ jra.1 1.3.2016.259-269.

Zonneveld, N., Huisman, E.A. \& Boon, J.H. 1991. Prinsip-Prinsip Budidaya Ikan. PT. Gramedia Pustaka Utama. Jakarta, 318 hlm. 